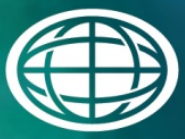

Savannah River

National Laboratory ${ }^{\mathrm{m}}$

OPERATED BY SAVANNAH RIVER NUCLEAR SOLUTIONS

\title{
Sample Results from the Next Generation Solvent Program Real Waste Extraction- Scrub-Strip Testing
}

T. B. Peters

A. L. Washington, II

June 2013

SRNL-STI-2013-00256, Rev. 0 
SRNL-STI-2013-00256

Revision 0

\section{DISCLAIMER}

This work was prepared under an agreement with and funded by the U.S. Government. Neither the U.S. Government or its employees, nor any of its contractors, subcontractors or their employees, makes any express or implied:

1. warranty or assumes any legal liability for the accuracy, completeness, or for the use or results of such use of any information, product, or process disclosed; or

2. representation that such use or results of such use would not infringe privately owned rights; or

3. endorsement or recommendation of any specifically identified commercial product, process, or service.

Any views and opinions of authors expressed in this work do not necessarily state or reflect those of the United States Government, or its contractors, or subcontractors.

\section{Printed in the United States of America \\ Prepared for \\ U.S. Department of Energy}


SRNL-STI-2013-00256

Revision 0

Keywords: $M C U, E S S, N G S$, Real

Waste, ISDP

Retention: Permanent

\section{Sample Results from the Next Generation Solvent Program Real Waste Extraction-Scrub-Strip Testing}

T. B. Peters

A. L. Washington, II

June 2013

Prepared for the U.S. Department of Energy under contract number DE-AC09-08SR22470.

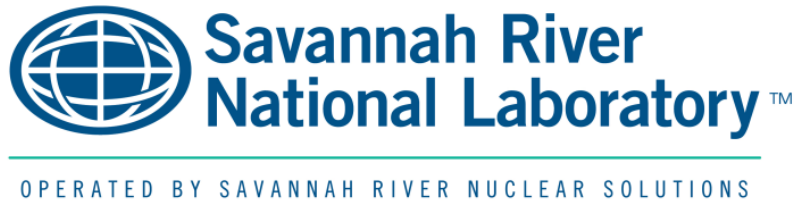




\section{REVIEWS AND APPROVALS}

\section{AUTHORS:}

T. B. Peters, Author, SRNL/ACP

Date

A. L. Washington, Co-author, SRNL/ACP

Date

TECHNICAL REVIEW: (Reviewed per E7 2.60)

C. A. Nash, Technical Reviewer, SRNL/ACP

Date

\section{APPROVAL:}

F. M. Pennebaker, SRNL/ACP, Manager

Date

S. L. Marra, SRNL/E\&CPT Research Programs, Manager

Date

E. A. Brass, Flowsheet Integration and Technology

Date

E. J. Freed, SRR Engineering

Date 
SRNL-STI-2013-00256

Revision 0

\section{EXECUTIVE SUMMARY}

Savannah River National Laboratory (SRNL) performed multiple Extraction-Scrub-Strip (ESS) testing using real waste solutions, and three Next Generation Solvent (NGS) variations, which included radiologically clean pure NGS, a blend of radiologically clean NGS and radiologically clean BOBCalixC6 (NGS-MCU), and a blend of radiologically clean NGS and radiologically contaminated BOBCalixC6 from the MCU Solvent system. The results from the tests indicate that both the NGS and the NGS-MCU blend exhibit adequate extraction, scrub and strip behavior. 


\section{LIST OF ABBREVIATIONS}

$\begin{array}{ll}\text { AD } & \text { Analytical Development } \\ \text { ARP } & \text { Actinide Removal Project } \\ \text { ESS } & \text { extraction, scrub, strip } \\ \text { ISDP } & \text { Interim Salt Disposition Program } \\ \text { MCU } & \text { Modular Caustic-side Solvent Extraction Unit } \\ \text { NGS } & \text { Next Generation Solvent } \\ \text { SHT } & \text { solvent hold tank } \\ \text { SRNL } & \text { Savannah River National Laboratory } \\ \text { SRR } & \text { Savannah River Remediation } \\ \text { TTQAP } & \text { Task Technical and Quality Assurance Plan } \\ \text { TTR } & \text { Technical Task Request } \\ \text { WAC } & \text { Waste Acceptance Criteria } \\ \text { \%RSD } & \text { percent relative standard deviation }\end{array}$




\subsection{Introduction}

This report details the results of the NGS and NGS-MCU tests (four in total) with real waste. The solvents used were three Next Generation Solvent (NGS) variations, which included radiologically clean pure NGS, a blend of radiologically clean NGS and radiologically clean BOBCalixC6 (NGS-MCU), and a blend of radiologically clean NGS and radiologically contaminated BOBCalixC6 from the MCU Solvent system.

This work was specified by Task Technical Request ${ }^{1}$ and by Task Technical and Quality Assurance Plan (TTQAP). ${ }^{2}$

Details for the work are contained in controlled laboratory notebooks. ${ }^{3}$

\subsection{Experimental Procedure}

Six Tank 21H samples (i.e., dip sample bottles HTF-21-12-96, HTF-21-12-97, HTF-2112-98, HTF-21-12-99, HTF-21-12-100, and HTF-21-12-101) arrived at SRNL on October 3, 2012. The samples were optically clear, with no visible solids present. Researchers measured the density of each of the solutions. With customer concurrence, the samples were combined and mixed. This material served as a qualification sample for Salt Batch 6, ${ }^{4}$ and the remaining material was saved for use for the NGS program.

The bulk chemical composition of this material is reported in Table 1.

Table 1. Tank 21H Composition

\begin{tabular}{|c|c|}
\hline Analyte & Result \\
\hline density & $1.304 \mathrm{~g} / \mathrm{mL}$ \\
\hline Free $\mathrm{OH}$ & $1.90 \mathrm{M}(10 \%)$ \\
\hline $\mathrm{NO}_{3}{ }^{-}$ & $2.23 \mathrm{M}(10 \%)$ \\
\hline $\mathrm{NO}_{2}{ }^{-}$ & $0.474 \mathrm{M}(10 \%)$ \\
\hline $\mathrm{Al}$ & $0.199 \mathrm{M}(10 \%)$ \\
\hline $\mathrm{K}$ & $0.0118 \mathrm{M}(10 \%)$ \\
\hline${ }^{137} \mathrm{Cs}$ & $1.28 \mathrm{E}+08(5.00 \%)(\mathrm{dpm} / \mathrm{mL})$ \\
\hline
\end{tabular}

The analytical uncertainty is typically $<1 \%$ for density measurements.

\subsection{ESS Test Conditions}

For the ESS tests, material from the Tank $21 \mathrm{H}$ composite was used. For each test, the researchers used a nominal starting volume of $80 \mathrm{~mL}$ of aqueous feed and $20 \mathrm{~mL}$ of prepared solvent. ${ }^{\Sigma}$ For the first test, the solvent was the pure NGS, of a composition listed in Table 2. For the second test, the solvent was a blended material "NGS-MCU".

\footnotetext{
$\Sigma$ This set of volumes for the extraction step corresponds to a 4:1 A:O volume ratio. In the scrub and strip tests, the A;O volume ratio was 1:3.75.
} 
This blended material was created from the current MCU solvent formulation ${ }^{\Upsilon}$ and a prepared solution that would create a blended material designed to mimic the MCU solvent during initial NGS operations (this preparation was of an initially nonradiologically contaminated material, or "non-rad"). ${ }^{5}$ For the third and fourth tests, the solvent was identical to the one used in the second test, except that the MCU solvent was actual samples from the MCU solvent hold tank (SHT). The used solvent was from the October 2012 quarterly samples ${ }^{6}$ for the third test and for the fourth test the solvent was from the January 2013 quarterly samples. ${ }^{7}$ The first two tests were run in parallel, at the same time. The last two tests were run individually.

Table 2. Solvent Composition in Each Test (M)

\begin{tabular}{|c|c|c|c|c|}
\hline Component & Test \#1 & Test \#2 & Test \#3 & Test \#4 \\
\hline MaxCalix & 0.0501 & 0.0465 & 0.0463 & 0.0464 \\
\hline BOBCalix & None added & 0.0035 & 0.00350 & 0.00348 \\
\hline Cs-7SB Modifier & 0.499 & 0.500 & 0.507 & 0.437 \\
\hline Trioctylamine & None added & 0.0015 & 0.0015 & 0.000637 \\
\hline TiDG & 0.00277 & 0.00325 & 0.00294 & 0.00305 \\
\hline Isopar L $\AA$ & balance & balance & balance & balance \\
\hline
\end{tabular}

All of the tests used the same general protocol as used in macrobatch qualification, although the scrub and strip solutions are different due to necessary changes in the solvent chemistry (scrub is $0.025 \mathrm{M} \mathrm{NaOH}$, strip is $0.01 \mathrm{M}$ boric acid). ${ }^{8}$

\subsection{Quality Assurance}

Requirements for performing reviews of technical reports and the extent of review are established in manual E7 2.60. SRNL documents the extent and type of review using the SRNL Technical Report Design Checklist contained in WSRC-IM-2002-00011, Rev. 2.

\subsection{Results and Discussion}

Table 3 shows the results from the ESS Test, corrected to the normal process operating temperatures (i.e., $23{ }^{\circ} \mathrm{C}$ for extraction and scrubbing and $33^{\circ} \mathrm{C}$ for stripping).

Table 3. Cesium Distribution Values for the NGS ESS Tests

\begin{tabular}{|c|c|c|c|c|c|c|c|}
\hline Test\# & Material & Extraction & Scrub\#1 & Scrub\#2 & Strip\#1 & Strip\#2 & Strip\#3 \\
\hline 1 & NGS & 77.3 & 5.05 & 3.48 & 0.00150 & 0.00137 & 1.81 \\
\hline 2 & NGS-MCU (non-rad) & 76.6 & 5.18 & 2.35 & 0.00165 & 0.000912 & 1.37 \\
\hline 3 & NGS-MCU (hot\#1) & 66.7 & 5.88 & 2.63 & 1.26 & 1.29 & 0.00139 \\
\hline 4 & NGS-MCU (hot\#2) & 72.5 & 5.81 & 3.18 & 0.00161 & 0.00104 & 0.01380 \\
\hline
\end{tabular}

\footnotetext{
${ }^{\Upsilon}$ This batch of solvent was originally prepared with no extractant as S2-NOBOB-T-WI (see WSRC-NB-2005-00060). The extractant was added later (see WSRC-NB-2007-00054).
} 
The first two tests - NGS and NGS-MCU (non-rad) gave virtually identical extraction and scrub and strip results, including anomalously high Strip\#3 results (results in red text color). There was no reason to assume that Strip\#3 was not viable, given the history of previous NGS ESS tests. Other than the strip\#3 results, the results were within expectations. These two tests were run at the same time, while using different organic phases lead SRNL to believe that there was some sort of error introduced into the third strip step. While considering what errors were possible the researchers received the results for the third test (NGS-MCU (hot\#1)). In this test, the extraction and scrub results were identical to the results in the first two tests, while the Strip\#3 results were normal. However, the Strip\#1 and \#2 results were anomalous in the third test (results in red text color).

In an attempt to confirm whether or not this behavior was endemic, a fourth ESS test was run. At the same time, a review of the $\mathrm{pH}$ measurements (using $\mathrm{pH}$ swipes) of each step in each test provided insight to the cause of the unusual results (Table 4).

Table 4. pH Values for the NGS ESS Test Strip Portions

\begin{tabular}{|c|c|c|c|c|}
\hline Test \# & Material & Strip\#1 & Strip\#2 & Strip\#3 \\
\hline 1 & NGS & 7 & 6 & 10 \\
\hline 2 & NGS-MCU (non-rad) & 7 & 6 & 10 \\
\hline 3 & NGS-MCU (hot\#1) & 10 & 10 & 4 \\
\hline 4 & NGS-MCU (hot\#2) & 7 & 6 & 6 \\
\hline & Typical Range & $7-9$ & $7-6$ & $5-6$ \\
\hline
\end{tabular}

The uncertainties on the $\mathrm{pH}$ measurements are typically $0.5 \mathrm{pH}$ unit.

In past NGS ESS tests, the pH results for the Strip\#1 samples are typically 7-9, and then drop to a $\mathrm{pH}$ of 5-6 by Strip\#3 (the drop is due to the initial small amounts of high $\mathrm{pH}$ aqueous carryover). In the first two tests, the Strip\#3 results showed both a high $\mathrm{pH}$ result (results in red text color), and a high distribution value, while the Strip\#1 and \#2 results showed normal behavior for both $\mathrm{pH}$ and distribution value. In the third test, the Strip\#1 and \#2 results showed high $\mathrm{pH}$ (results in red text color) and D values, while the Strip\#3 result showed normal behavior for both. It appears that due to a human error, scrub solution ( $0.025 \mathrm{M} \mathrm{NaOH})$ was used in place of strip acid (0.01 M boric acid) during those steps showing the unusual results.

The fourth ESS test was run with an extra level of oversight. In this test all the strip $\mathrm{pH}$ and $\mathrm{D}$ value results showed expected behavior. This data indicates that the wrong scrub and strip solutions were used during various parts of the testing.

This data demonstrates the ability of NGS and the NGS blend to successfully extract cesium from real SRS salt feed, and give virtually identical results. 
SRNL-STI-2013-00256

Revision 0

\subsection{ICPES results}

ICPES analyses of all 12 aqueous strip samples were performed (Table 5). In this table, shaded cells indicate steps that gave atypical results.

Table 5. ICPES Results from Strip Samples

\begin{tabular}{|c|c|c|c|c|}
\hline Test & Solvent & Step & B (mg/L) & Na (mg/L) \\
\hline 1 & NGS & strip\#1 & 102 & 10.4 \\
\hline 1 & NGS & strip\#2 & 108 & 6.03 \\
\hline 1 & NGS & strip\#3 & 8.39 & 586 \\
\hline 2 & NGS-MCU (non-rad) & strip\#1 & 95.7 & 11.7 \\
\hline 2 & NGS-MCU (non-rad) & strip\#2 & 126 & 3.77 \\
\hline 2 & NGS-MCU (non-rad) & strip\#3 & 9.31 & 591 \\
\hline 3 & NGS-MCU (hot\#1) & strip\#1 & $<0.199$ & 599 \\
\hline 3 & NGS-MCU (hot\#1) & strip\#2 & $<0.199$ & 605 \\
\hline 3 & NGS-MCU (hot\#1) & strip\#3 & 112 & 23.2 \\
\hline 4 & NGS-MCU (hot\#2) & strip\#1 & 102 & 33.6 \\
\hline 4 & NGS-MCU (hot\#2) & strip\#2 & 113 & 4.55 \\
\hline 4 & NGS-MCU (hot\#2) & strip\#3 & 119 & 41 \\
\hline
\end{tabular}

The ICPES analytical uncertainty is $10 \%$.

If during a test, scrub and strip solutions were accidently swapped, this becomes apparent in the ICPES results. The scrub solution is a $0.025 \mathrm{M} \mathrm{NaOH}$ solution $(\mathrm{Na}=575 \mathrm{mg} / \mathrm{L})$, while the strip solution is $0.01 \mathrm{M} \mathrm{H}_{3} \mathrm{BO}_{3}(\mathrm{~B}=108 \mathrm{mg} / \mathrm{L})$. The shaded cells all show precisely the pattern of results that would indicate scrub and strip solutions were accidently swapped - a high sodium ( $\sim 575 \mathrm{mg} / \mathrm{L})$ and low boron result ( $<10 \mathrm{mg} / \mathrm{L})$.

The last test (NGS-MCU (hot\#2)) has no such pattern, which corroborates the acceptable results in all strip tests.

\subsection{Quality Assurance}

Requirements for performing reviews of technical reports and the extent of review are established in manual E7 2.60. SRNL documents the extent and type of review using the SRNL Technical Report Design Checklist contained in WSRC-IM-2002-00011, Rev. 2.

\subsection{Conclusions}

- A demonstration of cesium extraction, scrubbing and stripping cesium mass transfer intended to partially mimic the MCU operations after addition of the NGS cocktail, yielded behavior within acceptable norms. The NGS-MCU solvent should behave essentially as the NGS solvent. The values indicate the cesium removal should be superior to the current MCU solvent, and are comparable to previous tests using NGS. 
- For the purposes of using modeling that only uses the cesium distribution values as inputs, SRNL proposes the following logic to distill the results of the four tests. For the extraction step, the results from all 4 tests will be averaged. For each scrub step, the results from all 4 tests will be averaged. For the strip \#1, \#2 steps, the averages of tests \#1, 2, and 4 will be used, omitting the flier results in test\#3. For the strip \#3 step, the value from test\#4 will be used, omitting the flier result in tests \#1, 2 and omitting the result in test\#3 (strip\#3 step is really functioning as a strip\#1 in that test). Given this logic, SRNL derives the following composite distribution values for systems using either pure NGS or NGS-MCU solvent.

- Extraction, 73.3

- $\quad$ Scrub 1, 5.48

- $\quad$ Scrub 2, 2.91

- Strip 1, 0.00159

- $\quad$ Strip 2, 0.00111

- $\quad$ Strip 30.0138 
SRNL-STI-2013-00256

Revision 0

\subsection{References}

1 E. T. Ketusky, "Qualification of Salt Batch 6 with NGS,” HLW-DWPF-TTR-20130005, November 20, 2012.

2 T. B. Peters and S. D. Fink, “Task Technical and Quality Assurance Plan for Cesium Mass Transfer Test With Next Generation Solvent (NGS) and Miscellaneous White Papers”, SRNL-RP-2012-00842, Rev. 0, December 2012.

3 T. B. Peters, “Next Generation Solvent”, SRNL-NB-2013-00032, May 14, 2013.

4 T. B. Peters and S. D. Fink, "Sample Results from the Interim Salt Disposition Program Macrobatch 6 Tank 21H Qualification Samples,” SRNL-STI-2012-00707, Rev. 0, December 2012

5 E. T. Ketusky, "Recommended Quantities of Solvent Constituents for Next Generation Solvent (NGS)”, SRR-SPT-2012-0039, November 7, 2012.

6 F. F. Fondeur, T. B. Peters, S. D. Fink, “Solvent Hold Tank Sample Results for MCU-12-488, MCU-12-489, MCU-12-490, MCU-12-491, MCU-12-492 and MCU12-493: Quarterly Sample from October 2012” SRNL-STI-2012-00770, Rev. 0”, January 2013.

7 F. F. Fondeur, T. B. Peters, S. D. Fink, "Solvent Hold Tank Sample Results for MCU-13-143, MCU-13-144, MCU-13-145, MCU-13-146, MCU-13-147 and MCU13-148: Quarterly Sample from January 2013” SRNL-STI-2013-00112, Rev. 0”, March 2013.

8 A. L. Washington II, T. B. Peters, S. D. Fink, "Sample Results from the Integrated Salt Disposition Program Macrobatch 6 Tank 21H Qualification MST and ESS Samples”, SRNL-STI-2013-00034, February 2013. 